\title{
THE COLD WAR AS COOPERATION
}


Also by Roger E. Kanet

ASIA IN SOVIET GLOBAL STRATEGY

(with Ray S. Cline and James Arnold Miller)

BACKGROUND TO CRISIS: POLICY AND POLITICS IN GIEREK'S POLAND (with Maurice D. Simon)

THE BEHAVIORAL REVOLUTION AND COMMUNIST STUDIES

THE LIMITS OF SOVIET POWER IN THE DEVELOPING WORLD: THERMIDOR IN THE REVOLUTIONARY STRUGGLE (with Edward A. Kolodziej)

ON THE ROAD TO COMMUNISM: ESSAYS ON SOVIET DOMESTIC AND FOREIGN POLITICS (with Ivan Volgyes)

SOVIET AND EAST EUROPEAN FOREIGN POLICY

SOVIET ECONOMIC AND POLITICAL RELATIONS WITH THE DEVELOPING WORLD (with Donna Bahry)

SOVIET FOREIGN POLICY AND EAST-WEST RELATIONS

SOVIET FOREIGN POLICY IN THE 1980s

THE SOVIET UNION AND THE DEVELOPING NATIONS

THE SOVIET UNION, EASTERN EUROPE AND THE DEVELOPING STATES WESTERN EUROPE IN SOVIET GLOBAL STRATEGY

(with Ray S. Cline and James Arnold Miller)

Also by Edward A. Kolodziej

MAKING AND MARKETING ARMS: THE FRENCH EXPERIENCE AND ITS IMPLICATIONS FOR THE INTERNATIONAL SYSTEM

FRENCH INTERNATIONAL POLICY UNDER DE GAULLE AND POMPIDOU: THE POLITICS OF GRANDEUR

THE UNCOMMON DEFENSE AND CONGRESS: 1945-1963

THE LIMITS OF SOVIET POWER IN THE DEVELOPING WORLD:

THERMIDOR IN THE REVOLUTIONARY STRUGGLE (with Roger E. Kanet) SECURITY AND ARMS CONTROL: A GUIDE TO NATIONAL

POLICYMAKING, vol. I (with Patrick Morgan)

SECURITY AND ARMS CONTROL: A GUIDE TO INTERNATIONAL

POLICYMAKING, vol. II (with Patrick Morgan)

AMERICAN SECURITY POLICY AND POLICYMAKING (with Robert Harkavy) SECURITY POLICIES OF DEVELOPING COUNTRIES (with Robert Harkavy) 


\section{The Cold War as Cooperation}

\section{Superpower Cooperation in Regional Conflict Management}

Edited by

Roger E. Kanet

Professor of Political Science

University of Illinois at Urbana-Champaign

and

Edward A. Kolodziej

Research Professor of Political Science

University of Illinois at Urbana-Champaign

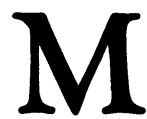

MACMILLAN 
(C) Roger E. Kanet and Edward A. Kolodziej 1991

Softcover reprint of the hardcover 1st edition 1991 978-0-333-52508-1

All rights reserved. No reproduction, copy or transmission of this publication may be made without written permission.

No paragraph of this publication may be reproduced, copied or transmitted save with written permission or in accordance with the provisions of the Copyright, Designs and Patents Act 1988, or under the terms of any licence permitting limited copying issued by the Copyright Licensing Agency, 33-4 Alfred Place, London WC1E 7DP.

Any person who does any unauthorised act in relation to this publication may be liable to criminal prosecution and civil claims for damages.

First published 1991

Published by

MACMILLAN ACADEMIC AND PROFESSIONAL LTD

Houndmills, Basingstoke, Hampshire RG21 2XS

and London

Companies and representatives

throughout the world

Filmset by Wearside Tradespools,

Fulwell, Sunderland

British Library Cataloguing in Publication Data

The cold war as cooperation: superpower cooperation in regional conflict management.

1. Soviet Union. Foreign relations with United States. 2. United States. Foreign relations with Soviet Union

I. Kanet, Roger E. 1936- II. Kolodziej, Edward A. 1935-

327.47073

ISBN 978-1-349-11607-2 ISBN 978-1-349-11605-8 (eBook)

DOI 10.1007/978-1-349-11605-8 


\section{Contents}

Acknowledgements

vii

Notes on the Contributors

ix

Preface

\section{Part I THE COLD WAR AS COOPERATION}

1 The Cold War as Cooperation Edward A. Kolodziej

2 The Cold War as Cooperation: A Soviet Perspective

Victor A. Kremenyuk

Part II SUPERPOWER COOPERATION IN CONFLICT MANAGEMENT: REGIONAL PERSPECTIVES

The Superpowers in Europe

3 Superpower Cooperation in Western Europe Edward A. Kolodziej

4 Superpower Cooperation in Eastern Europe Roger E. Kanet

The Superpowers in the Middle East and Africa

5 Superpower Cooperation in the Middle East Galia Golan

6 Superpower Cooperation in North Africa and the Horn

I. William Zartman

7 Superpower Cooperation in Central Africa Crawford Young

8 Superpower Cooperation in Southern Africa Daniel R. Kempton 
The Superpowers in Central and Latin America

9 Superpower Cooperation in the Caribbean and Central America

W. Raymond Duncan

10 Superpower Cooperation in South America

Howard J. Wiarda

The Superpowers in Asia

11 Superpower Cooperation in South Asia

Stephen P. Cohen

12 Superpower Cooperation in Southwest Asia Marvin G. Weinbaum

13 Superpower Cooperation in Southeast Asia Sheldon W. Simon

14 Superpower Cooperation in Northeast Asia Samuel S. Kim

\section{Part III CONCLUSIONS}

15 The Shadow of the Future in Light of the Past Edward A. Kolodziej

Index of Cases of Superpower Cooperation

James M. Finlay

Index 


\section{Acknowledgements}

The editors wish to express their sincere appreciation to all of those who made the project and this resulting study possible. The original idea of a study of superpower cooperation emerged out of an earlier project in which many of the contributors to this book were also involved. In the course of carrying out the research included in The Limits of Soviet Power in the Developing World: Thermidor in the Revolutionary Struggle (Macmillan and Johns Hopkins, 1989), it became evident that superpower conflict and competition were accompanied by persistent cooperation. As the editors traced USSoviet competition in regional conflicts since World War II, the concept of cooperation based on a game-theoretic understanding of that term provided one important key to explaining the dilemma of why a cold war could arise and why it is is now coming to an end. This volume is one attempt to relax, if not resolve, this dilemma.

A key element in the preparation and emergence of the present study was a major workshop on the cooperative aspects of the superpower relationship throughout the entire postwar period. This workshop was held at the University of Illinois at Urbana-Champaign on 4-6 May 1989. Contributors and invited guests, most of whom had already met in smaller groups to work out the details of the theoretical framework of the project, came together to address the issue of cooperation within the context of conflict in the postwar US-Soviet relationship. In addition to the primary contributors who presented the initial drafts of the papers included here, Frederick $S$. Pearson of the Wayne State University in Detroit and David W. Tarr of the University of Wisconsin, Madison, served as formal commentators and provided detailed written comments on the papers. Terry D. Clark and James M. Finlay, both of the University of Illinois at Urbana-Champaign, served as rapporteurs.

The editors wish to express their appreciation to all the participants whose perceptive criticisms and suggestions resulted in greater clarity and precision in the final drafts of the individual papers. They also wish to thank James Finlay for the index of cases of superpower cooperation that he prepared. This index is drawn from the regional chapters and is designed to assist scholars and analysts who, like the authors of the volume, wish to pursue further and test the thesis that the Cold War can be understood as an epic effort to decide the 
political order and socio-economic welfare system of the emerging world society and the principles of legitimacy on which it should rest.

The editors are also grateful for the support provided for the workshop by the Program in Arms Control, Disarmament and International Security and the Department of Political Science, both of the University of Illinois at Urbana-Champaign. Moreover, without the substantial financial backing of the Midwest Consortium for International Security Studies (a program managed by the Midwest Center of the American Academy of Arts and Sciences and funded by the MacArthur Foundation) and the National Defense University, the workshop would not have been possible. The editors wish to give special thanks to Russell Hardin and Marian Rice of the former organization, and to Robert Butterworth of the latter for their role in providing that support. Of course, the views, opinions, and findings contained in this book are those of the authors and should not be construed as an official position of either the Midwest Consortium or the National Defense University.

The editors also wish to thank all of the other authors for their willingness to revise their chapters, taking into account the recommendations from workshop participants and the sometimes stringent demands of the editors; thanks are also due to Barbara Cohen for preparing the subject index. Finally they wish to acknowledge the essential role of the secretarial staff in the Department of Political Science - especially Janie Carroll, Mary Anne Heiderscheit, and Peggy Currid - who dealt effectively and patiently with 'incompatible' computer programs, illegible handwriting, and related problems.

ROGER E. KANET EDWARD A. KOLODZIEJ 


\section{Notes on the Contributors}

Stephen P. Cohen is Professor of Political Science at the University of Illinois at Urbana-Champaign and director of the University's Program in Regional Security Studies. He served as a member of the Policy Planning Staff of the US Department of State during 1985-7. Dr Cohen is the author or co-author of numerous books and articles on security questions in South Asia, including The Indian Army (1971), The Pakistan Army (1984), and (ed.) The Security of South Asia: Asian and American Perspectives (1987). He also contributed to The Limits of Soviet Power in the Developing World (1989).

W. Raymond Duncan is Distinguished Teaching Professor of Political Science at the State University of New York, College at Brockport. During 1984-6 he was Scholar-in-Residence with the Central Intelligence Agency, where he worked on Soviet-Third World relations. Included among his many publications are his most recent books, The Soviet Union and Cuba: Interests and Influence (1985) and with Carolyn McGiffert Ekidahl Moscow and the Third World Under Gorbachev (1990). He also contributed to The Limits of Soviet Power in the Developing World (1989).

Galia Golan is Jay and Leonie Darwin Professor of Social Studies and Chair of the Department of Political Science at the Hebrew University, Jerusalem. Among her numerous publications on aspects of Soviet foreign policy are The Soviet Union and the Palestine Liberation Organization (1980), Yom Kippur and After: The Soviet Union and the Middle East Crisis (1977), The Soviet Union and National Liberation Movements in the Third World (1988), Gorbachev's 'New Thinking' on Terrorism (1990), and Soviet Policies in the Middle East since World War Two (1990).

Roger E. Kanet is Associate Vice Chancellor for Academic Affairs and Director of International Programs and Studies, as well as Professor of Political Science, at the University of Illinois at UrbanaChampaign. Included among his publications are: (ed.) Soviet Foreign Policy and East-West Relations (1982), (ed.) Soviet Foreign Policy in the 1980s (1982), (ed.) The Soviet Union, Eastern Europe and the Third World (1987), and (ed.) The Limits of Soviet Power in 
the Developing World: Thermidor in the Revolutionary Struggle (1989).

Daniel R. Kempton is Assistant Professor of Political Science at Northern Illinois University. Included among his publications is Soviet Strategy Toward Southern Africa: The National Liberation Movement Connection (1989). He also contributed a bibliography on Soviet foreign policy to The Limits of Soviet Power in the Developing World (1989).

Samuel S. Kim is a member of the faculty of the Woodrow Wilson School of Public and International Affairs of Princeton University. He has written widely on Chinese foreign policy, US policy in East Asia, and the international relations of East Asia. Included among his publications are China, the United Nations, and World Order (1979), China in the Global Community (1980), The Quest for a Just World Order (1984), and China and the World (1989).

Edward A. Kolodziej is Research Professor of Political Science at the University of Illinois at Urbana-Champaign. His research and teaching interests focus on two related concerns: the role of military force and threats in international relations and the arms control and security problems in Europe. Among his major publications are: The Uncommon Defense and Congress: 1945-1963 (1966), French International Policy under De Gaulle and Pompidou: The Politics of Grandeur (1974), and Making and Marketing Arms: The French Experience and Its Implications for the International System (1987). He was co-editor of The Limits of Soviet Power in the Developing World: Thermidor in the Revolutionary Struggle (1989).

Victor A. Kremenyuk has been Associate Director of the Institute for the Study of the USA and Canada of the Academy of Sciences of the USSR since 1989, and Department Head at the Institute since 1978. $\mathrm{He}$ is author of numerous studies of US foreign policy, in particular on US policy toward the developing world. These include, in Russian, US Foreign Policy in the Third World (1977), US Policy Toward National Liberation Movements, 1945-1980 (1983), Problems of Non-Alignment (1986) and, in English, USA and Dependent Regimes (1981), International Conflict Resolution (1988), and four contributions to Graham T. Allison and William L. Ury (eds), 
Windows of Opportunity: From Cold War to Peaceful Competition in US-Soviet Relations (1989).

Sheldon W. Simon is Professor of Political Science and Faculty Associate of Arizona State University's Center for Asian Studies. He also serves as a consultant with the US Information Agency and the Department of Defense. He has written extensively on Asian foreign and security policies and is the author or editor of six books, including The ASEAN States and Regional Security (1982) and The Future of Asian-Pacific, Security Collaboration (1988). He also contributed to The Limits of Soviet Power in the Developing World (1989).

Marvin G. Weinbaum is Professor of Political Science and Director of the Program in South and West Asian Studies at the University of Illinois at Urbana-Champaign. He has written widely about Afghan domestic and foreign politics. Among his recent publications are also Food, Development and Politics in the Middle East (1982) and Egypt and the Politics of US Economic Aid (1986). He spent spring semester 1990 in Peshawar, Pakistan, where he conducted research on prospects for Afghan postwar reconstruction. He contributed to The Limits of Soviet Power in the Developing World (1989).

Howard J. Wiarda is Professor of Political Science and of Comparative Labor Relations at the University of Massachusetts/Amherst, and Research Associate of the Center for International Studies, Harvard University. Until 1988 he served as Resident Scholar and Director of the Center for Hemispheric Studies at the American Enterprise Institute for Public Policy Research. He is the author or editor of fifteen books, including (with Harvey Kline) Latin American Politics and Development (3rd edn, 1990), (ed.) Rift and Revolution: The Central American Imbroglio (1984), New Directions in Comparative Politics (1985), and (with Mark Falcoff and others) The Communist Challenge in the Caribbean and Central America (1987), Foreign Policy without Illusions (1990), The Democratic Revolution in Latin America (1990). He also contributed to The Limits of Soviet Power in the Developing World (1989).

Crawford Young is Professor of Political Science at the University of Wisconsin, Madison, where he has served as chair of both the 
Department of Political Science and the African Studies Program. His many publications on domestic and international politics in Africa include The Politics of Cultural Pluralism (1976), Cooperatives and Development (1982), Ideology and Development in Africa (1982), and The Rise and Decline of the Zairian State (1985). He also served as a formal commentator on the project that resulted in The Limits of Soviet Power in the Developing World (1989).

I. William Zartman is Jacob Baustein Professor of International Organization and Conflict Resolution and Director of the African Studies Program at the Johns Hopkins School of Advanced International Studies. He is the author and editor of a number of books on North Africa, including Man, State and Society in the Contemporary Maghreb (1974), Elites in the Middle East (1980), and The Political Economy of Morocco (1987). Professor Zartman has also written extensively on African politics and relations, with his latest work including Ripe for Resolution: Conflict and Intervention in Africa (1985), and, as editor, The Political Economy of Nigeria (1983), and The OAU after Twenty Years (1984). He also contributed to The Limits of Soviet Power in the Developing World (1989). 


\section{Preface}

Measured by the blood and treasure marshalled and directed in its pursuit, the Cold War must be reckoned among the great epics in human history. Unprecedented quantities of wealth and hundreds of millions of people from nations around the world were absorbed in this endeavor. Unlike Homer's Iliad and Odyssey, it was not limited to two peoples washed by common waters. It spread and sprawled to the far reaches of the globe, sparking wars - Korea and Vietnam most notably - and stirring civil strife along its path.

Among the many puzzles that the superpower struggle prompts, quite aside from its causes and consequences, is the question why the Cold War did not result in a global conflagration similar to the great power conflicts that led to the Napoleonic wars and to two world wars in this century. This volume attempts to supply a partial answer to this question. By that token it also contributes to an explanation of why the Cold War is rapidly drawing to a close and why the Cold War experience may be viewed as a necessary bridge between a lamentably devastating war-ridden past to a more productive or, at least, less destructive future.

Following the principle that the simplest solution to a problem is the best, this volume argues that the Cold War was cooperative from start to finish. Chapter 1 explains this paradoxical proposition. Situating the superpower struggle in a historical setting created by over four centuries of nation-state competition, this volume portrays the Soviet-American competition as the last in a line of Big Powerattempts to define the structures of world political order and economy to suit their preferences and to base those structures, putatively, on principles of authority of universal worth and legitimacy. The Cold War served the aims and interests of the superpowers and for a long time those of many nations and peoples in the developed and developing world. It catalyzed, for example, the process that culminated in the globalization of the nation-state as the principal unit of authority in the world society. Except for close calls, like the Cuban Missile crisis and a series of Berlin crises, the leadership of each superpower was careful to signal to its rival-partner that their regional conflicts could be managed short of general war, the traditional international instrument to settle profound national clashes over interests and values. Even in these crises, superpower 
diplomacy was marked by a prudence and restraint that was sometimes belied by the bombast and threats issuing from leadership circles.

In the logic of game theory, each superpower has had to learn to cooperate - mostly implicitly, sometimes explicitly - with its adversary to coordinate their mutually contingent behavior to avoid the worst consequences of their competition and to maximize the differential gains of compromises. They also had to develop rules of engagement and disengagement to regulate their conflict, as well as those of their allies and clients. These implicit and explicit compromises on outcomes and conflict processes essentially formed an institutional structure on which the superpowers could provisionally rely in pursuing their discord within an evolving and enlarging set of understandings, and of tolerable and legitimate practices in pressing their respective national and systemic claims.

The regional chapters below attempt to apply this conceptual framework to the superpower struggle since World War II. Each author is a specialist who has an intimate knowledge not only of the politics and local cleavages but also of superpower behaviour and stakes in his or her region. The editors charged each contributor to draw on his or her knowledge and experience and, speaking ex cathedra, to identify the lines of superpower cooperative behavior within the meaning of the term used in this volume.

As a collaborative exercise, the editors and contributors trust that the final product will be greater than the sum of the individual parts. Dr Victor Kremenyuk's important contribution encourages this view. Across the barriers of language, culture, and a bitter and costly Cold War, Dr Kremenyuk and the other authors struck an immediate rapport when we first met in a conference on the campus of the University of Illinois in May 1989. Dr Kremenyuk, who has been honored by the Soviet Academy of Sciences for his contribution to conflict resolution and mediation theory and practice, assumed a leading role in the vigorous and sometimes heated discussions leading to adoption of a common conceptual framework and to the game theoretic notion of cooperation underlying this volume. Cooperation is understood in broad enough terms to encompass, paradoxically, the surface phenomena of superpower conflict as well as the coordinated choices of otherwise apparently irreconcilable foes.

The final chapter echoes and elaborates on Dr Kremenyuk's view that the past, i.e. the Cold War, has to be understood as cooperation, if it is to be successfully surmounted by the United States, the Soviet 
Union, and other leading nations of the world. The regional chapters furnish prima facie evidence for the proposition that there has been more superpower cooperation than may initially strike the eye of the untutored observer. This experience and the expectations that it has generated among ruling elites in the United States and the Soviet Union provide a foundation on which to build toward a more peaceful and prosperous world and to define principles of political authority that apply across national boundaries and that approach system-wide acceptance to guide international conduct.

The volume is one attempt to get below the surface appearance of seemingly irremediable conflict to reveal the ill-formed, loose, and unsymmetrical cooperative webbing that underlay the Cold War. Chapter 1 differentiates the approach of this volume from several other parallel efforts. Unlike Penelope's tapestry, unraveled daily to await a better future, the fabric of superpower cooperation promises to be more durable and lasting cloth than the conflict that instigated the chain of decisions and actions that, not always wittingly designed, now comprise its warp and woof. As the Cold War recedes as a force, the remembrance of those cooperative experiences and of the limited but mutually beneficial results of superpower cooperation can be projected into the future to inform expectations in foreign capitals about the risks and likelihood of multiplying the frequency and scope of cooperation not only between the superpowers but also among the other nation-states of the globe. The shadow of the future can be seen, however dimly, in light of the past.

ROGER E. KANET EDWARD A. KolodziEJ Urbana-Champaign, Illinois 